\title{
Calixthe Beyala: Black Face(s) on French TV
}

\author{
Dr Nicki Hitchcott \\ Department of French \\ University of Nottingham \\ Nottingham \\ NG7 2RD
}

Tel. 01159515868

Fax 01159514998

email nicki.hitchcott@ nottingham.ac.uk 


\section{$\underline{\text { Calixthe Beyala: Black Face(s) on French TV }}$}

Je suis établie en France parce que les conditions sociologiques en Afrique ne me permettent pas d'écrire; on est happé par les exigences de la vie quotidienne. Et puis ma voix ne servirait à rien en Afrique. Ici, je profite des médias pour faire passer mon message. ${ }^{1}$

As president and spokeswoman of the French black rights movement, Collectif Egalité, Cameroonian-born novelist, Calixthe Beyala, is committed to pushing for an improvement in the representation of black people on television in France. ${ }^{2}$ According to Beyala, TV images of black drug dealers, thieves and murderers lead to problems of identification for the children of ethnic minorities in France. ${ }^{3}$ Only in the 1990s did black faces begin to appear in anything other than news items and TV documentaries in France, that is twenty years later than the UK, where the first multicultural sitcoms were broadcast in the 1970s. ${ }^{4}$ Black actors have rarely been employed in positive roles on French television, except occasionally as police officers, and then almost never in the lead. When cast as the eponymous junior doctor in the 2001 France 3 series, 'Fabien Cosma', mixed-race actor, Louis-Karim Nébati hoped that his new role would contribute to the 'normalization' of black faces on French TV. He explains, Je n'ai pas dit intégration! C'est un mot politique qui implique une différenciation au départ. Or, il faut espérer qu'un jour les téléspectateurs ne s'arrêteront même plus à ce 'détail épidermique', qu'ils trouveront 100\% naturel de voir un comédien black ou beur ou asiatique dans un rôle d'architecte, de chef d'entreprise, de professeur, de ministre... 
This article will discuss the ways in which the Collectif, under the presidency of Calixthe Beyala, has attempted to draw the French public's attention to the lack of black faces on television in France. It will also take as a test case, the controversial figure of Beyala herself who has become something of a minor TV star in her own right. What will emerge as an apparent contradiction between Beyala's own media representation and the Collectif's campaign will serve to illustrate the ambivalent positioning of black citizens in France.

In 1999, refusing to pay their TV licence fee, members of the Collectif approached French government ministers as well as the national broadcasting regulatory body, the Conseil Supérieur de l'Audiovisuel (CSA) about the lack of what they refer to as 'les minorités visibles' on terrestrial television. Beyala explains, 'il faut savoir que l'Etat nous exclut dans le silence, que les services publics collaborent à un fascisme silencieux et pernicieux: la préférence nationale' ${ }^{6}$ Of course, this 'préférence nationale', as the Collectif suggests, does not in fact reflect the whole of the nation, since French citizens of black and Maghrebian descent are anything but visible in public broadcasting.

Of the French government ministers contacted by the Collectif, only Martine Aubry responded - unsatisfactorily in Beyala's view - by quoting the example of 'Saga-Cités' on France 3, and proposing to set up a group to monitor racism on TV. On the other hand, Hervé Bourges, then president of the CSA, was receptive to the Collectif's position and, in 1999, agreed to commission a review of the French terrestrial channel remits. This agreement followed an initial meeting, on 5 October 1999, between Bourges and the Collectif. Letters were subsequently addressed to the heads of all the terrestrial channels as well as to Catherine Trautmann and her successor, Catherine Tasca. These letters called for a revision of the 'cahiers des 
missions et des charges' in order to guarantee better representation of ethnic minorities in public broadcasting. Catherine Tasca took up the gauntlet and, on 16 May 2000, the CSA approved a proposal to revise the broadcasting remits for France 2 and France 3, noting that 'le projet de décret vise à renforcer les missions de service public dont sont investies France 2 et France 3 en les incitant à tenir compte dans leur programmation de la réalité pluriethnique et pluriculturelle de la société française contemporaine'. ${ }^{8}$ The CSA also recommended that the different ethnic groups of French society should be represented on television screens and that the private channels should follow the example of France 2 and France 3.

The CSA review also commissioned the second major study of French television's representation of ethnic minorities. ${ }^{9}$ The project, entitled Présence et representation des 'minorités visibles' à la télévision française, was co-ordinated by Marie-France Malonga, and focused on the number and types of representation of people of Black African, Maghrebian or Asian descent in one week of programmes (11-17 October 1999) on five French terrestrial channels (TF1, France 2, France 3, Canal + and M6) between 5pm and midnight. ${ }^{10}$

As Malonga explains, the decision to adopt a quantitative analysis of ethnic minorities on French television was an impossible task since the French national census does not take account of ethnic origin; to do so would go against the French concept of nationhood. ${ }^{11}$ This means that the number of French nationals of ethnic origin is not known, so to talk in terms of proportional representation would be meaningless. Regrettably, while Malonga's report reveals the question to be one that requires a qualitative rather than a quantitive approach, lack of time and funding meant that a comprehensive qualitative analysis was not completed. ${ }^{12}$ The CSA study does, however, draw the following conclusions: 
- Actors of ethnic origin tend to play minor roles on French television and are rarely in the lead

- $75 \%$ of 'visible minorities' appear in foreign TV shows (particularly American imports)

- 'Visible minorities' are rarely shown as fully integrated members of French society

- Each minority group is presented as homogeneous and often stereotyped

- French people of ethnic origin are often associated with topics of an antisocial nature $^{13}$

What is immediately revealed by these conclusions is the continued 'othering' of the non-white population of France. As Malonga states, 'they automatically come from "elsewhere" [...]. Ethnic minorities, because of their difference (which for many is mostly physical) seem to be considered as 'permanent foreigners', regardless of nationality. ${ }^{14}$

At the time of the CSA study, the Collectif Egalite was beginning to acquire a certain level of notoriety in the French media with its proposal for a system of quotas for TV performers based on racial criteria. Harlem Désir, former president of SOSRacisme and now a Euro-MP, along with Zaïr Kedadouche, president of Intégration France, published statements in the press condemning the proposed quotas. ${ }^{15}$ While Désir and Kedadouche support the Collectif's condemnation of the lack of positive images of blackness on French television, both would view the introduction of quotas as a potential threat to the unity of the Republic. For the same reason, SOS-Racisme has chosen to distance itself from the Collectif as has the MRAP, ${ }^{16}$ whose leader Mouloud Aounit explains, 'Il [le Collectif Egalité] pose les bonnes questions mais la réponse est pire que le mal. On n'agit pas contre le racisme au nom d'une minorité, 
mais au nom du droit et de la République'. ${ }^{17}$ Zaïr Kedadouche goes so far as to say that the implementation of quotas would amount to 'un racisme à l'envers' ${ }^{18}$ Such comments only serve to demonstrate Pascal Blanchard and Nicholas Bancel's criticism of the anti-racist movement in France, which they describe as 'victime de son incompréhension de la nature historique des représentations des immigrés excolonisés' ${ }^{19}$ Furthermore, as Beyala herself has argued, the media furore around the suggestion of quotas has successfully created a smokescreen that prevents the French public from taking the demands of the Collectif seriously. ${ }^{20}$

On 19 February 2000, Calixthe Beyala and Guadeloupean actor/director, Luc Saint-Eloi, gate crashed the $25^{\text {th }}$ annual César ceremony, walking on stage during the performance to read a public statement to then Minister of Culture, Catherine Trautmann, about the lack of black actors in French cinema, and to award a posthumous ‘unofficial César' to Darling Legitimus, star of Euzhan Palcy’s film, $\underline{\text { Rue }}$ cases-nègres. ${ }^{21}$ Interestingly, in the televised recording of the ceremony, the director undermines Beyala and Saint-Eloi's message by increasing the number of reverse shots while they read their statement, switching the camera back to the audience and zooming in on individual black faces. The camerawork seems to suggest that the Collectif do not, in fact, have a case, despite the fact that, as Beyala and Saint-Eloi point out, no César has ever been awarded to a member of an ethnic minority in France. What emerges is an unsettling parody of the situation the Collectif describe: even when two black people take centre stage in a French TV programme (albeit illegitimately), they are marginalized and undermined by the director's - and the spectator's - gaze.

The César ceremony is by no means Beyala's only TV appearance. On the contrary, despite the CSA's finding that only $11 \%$ of French television guests are 
from black, Maghrebian or Asian origin, Calixthe Beyala herself is no stranger to the small screen. ${ }^{22}$ Indeed, she has been described in Elle magazine as 'pleine de [...] télégénie'. ${ }^{23}$ Since the publication of her first novel in 1987, Beyala has become an increasingly frequent presence on French television. In 1996, the year in which Beyala won the prestigious Grand Prix de l'Académie Française for her seventh novel, Les Honneurs perdus, she appeared at least twelve times on terrestrial television in France. ${ }^{24}$ As invited TV guest or 'expert', Beyala has voiced her opinions on a range of subjects, including: whether women can live without men, ${ }^{25}$ Brigitte Bardot's memoirs, ${ }^{26}$ retirement homes,${ }^{27}$ and chocolate. ${ }^{28}$

It is perhaps partly Beyala's political role as Collectif spokeswoman and agitator that explains her desire to appear on a range of French TV programmes, many of them talk shows or magazine programmes broadcast during the day. Yet, as a minor TV celebrity in her own right, the figure of Calixthe Beyala adds another dimension to the question of the visibility of ethnic minorities on the French small screen. Whilst it is true that her television appearances are generally motivated by the promotion of her books, Beyala has at the same time become something of an icon of African femininity in France. Reinforcing Maggie Allison's conclusion that 'the mainstream media [in France] still, for the most part, see women public andpoliticl figures as predominantly sexual beings within a heterosexual framework, hampering their representation in both senses of the word', (p.76), Beyala's interviewers constantly draw attention to her physical appearance (Beyala is a former model); ${ }^{29}$ camera operators often focus on her legs; and even in discussions of her fiction, such distinguished TV presenters as Patrick Poivre d'Arvor point to the erotic qualities of her writing. ${ }^{30}$ Surprisingly, perhaps, Beyala herself never challenges the ways in which she is constantly constructed as an exotic object of beauty; on the contrary, she 
often flirts with presenters, telling them that her given name, Calixthe, means 'la plus jolie' in Greek. ${ }^{31}$

In 1988, Beyala appeared for the second time on Antenne 2's morning magazine programme, 'Matin Bonheur' with Thierry Becarro. During this programme, Becarro mispronounces Beyala's name no less than ten times in fortyfive minutes. When Becarro eventually realises his mistake and apologises to Beyala, she laughs. The apology follows a sexually charged interaction during which Becarro reacts to the news of Beyala's advanced pregnancy by telling her, 'C'est bien! Vous êtes superbe! Je me permets de vous le dire'. The show culminates in a cookery demonstration. Here Beyala comments, 'Je suis tellement gourmande que j'ai envie de sauter dessus! ${ }^{32}$ Thus, from an early stage in her television career, Beyala seems prepared to accept and also to reinforce the media's positioning of her as the exotic/erotic other. Of course, stereotypes of African women as both exotically beautiful and sexually voracious hark back to the colonial era, the epitome being Saartje Baartman, nicknamed 'The Hottentot Venus'. It is surprising, then, that a woman who wishes to challenge the representation of blacks on French TV should appear to implicitly legitimize her own mystification by the media and at the same time allow the perpetuation of the discourse of colonial fantasy.

In 1993, Beyala was invited to participate a debate about sex in the TF1 discussion programme, 'Durand la Nuit'. Here, she plays an intriguing game, confirming racist stereotypes when she claims, to the delight of the audience, that in Africa 'on baise vraiment' and then subsequently feigning outrage when gallery owner, Sylvana Lorentz, flings what she later admits to be a racist insult at Beyala, that is: 'Il ne faut pas tout prendre au premier degré, comme Madame [Beyala], comme en Afrique'. 33 
Yet, Beyala's TV persona is not confined to that of sexualized and racialized other; she also has a reputation for being something of a loudmouth, as Emmanuelle Pontiée explains: '[elle est] parfois critiquée pour ses interventions médiatiques tonitruantes et ses coups de gueule réguliers'. ${ }^{34}$ In 1995, Beyala made an appearance on the afternoon magazine series 'Ça se discute' in a programme provocatively entitled, 'L'Avenir est-il aux garces?' Here she is marginalized by the other participants as an angry extremist. This broadcast coincides with the publication of Beyala's first essay, Lettre d'une Africaine à ses soeurs occidentales, the most explicitly feminist of her writings. ${ }^{35}$ During the programme, Beyala waves her finger and shouts, claiming, in no uncertain terms, that women are superior to men. Four years later, Beyala falls into a verbal slanging match with radio presenter, Michel Polac, on the late night chat show, 'Tout le monde en parle'. Polac eventually walks off the set, having initially greeted Beyala with the words, 'J'ai toujours un peu peur quand je la [Beyala] vois parce qu'elle sort des grosses conneries [...] Elle est toujours à prendre des positions extrêmes et ça me fatigue énormément' ${ }^{36}$ Ironically, this show was broadcast at the same time as the Collectif Egalité was holding meetings with the CSA to challenge the representation of black people on French TV. Having been reduced by Michel Polac to the figure of a vulgar extremist, Beyala is then invited by the show's host, Thierry Ardisson, to discuss the question of 'les minorités visibles' on TV. This discussion is consistently undermined by M6 presenters, Charly and Lulu, cracking jokes. The fact that Charly, another of the rare black faces on French television fails to recognise the seriousness of the issue scrambles Beyala's argument and marginalizes her once more.

Even after several television appearances in which the question of the representation of ethnic minorities was her main talking point, Beyala remains fixed 
in the media stereotype created for her in the late 1980s. Fellow guests on the latenight magazine programme, 'On a tout essayé!', broadcast in October 2000 make numerous comments on Beyala's physical appearance, including 'Vous êtes plutôt une belle femme!' and 'Elle est ravissante'. Beyala had been invited to present her novel, Comment cuisiner son mari à l'africaine, which is described as in the show as 'un petit peu de l'Afrique folklore mais c'est bien écrit'. ${ }^{37}$ Rather than discuss the fiction of this prize-winning author in any meaningful way, the participants choose instead to focus on Beyala as a figure of erotic otherness.

What these television programmes demonstrate is the French media's attempt to fix Calixthe Beyala within two colonial models: the exotic beauty and the savage. Writing about cinema, Homi Bhabha has famously argued that 'an important feature of colonial discourse is its dependence on the concept of "fixity" in the ideological construction of otherness' ${ }^{38}$ French television is thus perpetuating a colonial discourse in its representation of black celebrities like Beyala, and simultaneously forestalling any notion of a multi-cultural France. As exotic beauty or savage, the figure of Beyala on TV serves to illustrate the conclusions of the CSA study discussed above: French television - and the French media in general - has unquestioningly inherited the historical legacy of stereotyped visual images of the former colonial 'other'. ${ }^{39}$ The televisual 'othering' of Beyala has important implications not just for black TV audiences in France but for the entire nation, as Karen Ross, writing about representations of black people on British film and television, suggests:

In the relative absence of black images, those which are available take on iconic dimensions, signifying in one constructed image, the complex of diverse and heterogeneous communities, reducing individual uniqueness to a false and essentialized black 'other'. As part of the enterprise of reinventing 
nation-states, the mass media have a primary role in standardizing representation and language, in normalizing the circulation and promotion of dominant values. They play an important part in reproducing and strengthening nationalist sentiments. ${ }^{40}$

Another of the few well-known black faces on French TV, Navarro star, Jacques Martial, makes a similar point when he remarks that television serves to build the collective imagination of the (predominantly white) entire nation. ${ }^{41}$ In the case of Calixthe Beyala, French television is normalizing and promoting an essentialised (and racist) stereotype of the black African woman.

As an erotic-exotic object, the image of Beyala on TV can be read as France's continued attempt to justify the 'mission civilisatrice' of its colonial endeavour. Ross writes:

We are all products of our history, culture and socialization and we all function within a specific cultural framework of dominant norms and values. Thus it matters little what the avowed intention of a film or programme-maker actually is, the resulting product can too easily be framed within an imperialist (and inherently exploitative) code, of 'us' looking in on 'them' - yet more exotic spectacle on which to gaze. ${ }^{42}$

It is, however, difficult to reconcile what Beyala's apparent participation in this normalization of colonial discourse with her role as prominent campaigner for equality of representation. One reading of Beyala on TV might identify her as yet another example of the paradoxical way in which some women in France are, as Allison remarks, 'ambivalent towards or unconcerned by the tradition of the French male seducer'. ${ }^{43}$ However, what appears to be a degree of complicity, on Beyala's part, with what Allison terms the "“French seduction" syndrome' reflects, I would like 
to suggest, the difficulty of finding a space for black women in contemporary France. Of course, Beyala's TV performances also could be read simply as a strategic quest for stardom in a country in which the integration of black African immigrants remains a subject of controversy. Indeed, her different incarnations present Beyala as something of a performer, playing to the images created for her by the French media. However, such a game would have very serious implications for the representation of ethnic minorities - and black women in particular - on television in France. On the other hand, Beyala's protean media image could be read as a sign of her uncertainty about how to position herself in the French public eye and, by extension, within the French nation-state. As Dominic Thomas illustrates in a discussion of her nonfictional writings, Beyala's self-positionality has shifted from 'Africaine' (in 1995) to the more ambiguous hyphenated identity: 'Afro-française' (in 2000). ${ }^{44}$ On television, however, Beyala sometimes prefers to position herself in a space where there is seemingly less ambiguity, telling host, Philippe Bouvard, in 2000:

Je suis plus française que vous. Je connais une plus grande partie de la culture française que $90 \%$ de mes compatriotes. Donc suis-je immigrée? Je ne pense pas. Je pense dire de moi que je suis immigrée, c'est presque une injure. Je ne suis pas immigrée en France. Je suis chez moi. C'est ma terre. Je l'aime. J'y vis et j'y demande des droits. Et d'ailleurs, je vais vous signaler, Philippe, que si je ne contestais pas, je serais une mauvaise Française. ${ }^{45}$

According to Blanchard and Bancel, the politics of integration in France has generated two models of identity for immigrants from the former empire: the 'assimilated' or the 'rebel'. ${ }^{46}$ What Beyala's media career reveals is a woman struggling to position herself between these poles, sometimes as assimilated, sometimes as rebel, sometimes as neither, sometimes as both. Unfortunately, as a 
media icon of black femininity, Calixthe Beyala, like her Collectif Egalité, has so far failed to produce any real change in the negative status quo. Whilst television can play an important role in the integration of marginalized communities, it can also reinforce social division. As Marie-France Malonga's work has shown, the representation of ethnic minorities on French TV amounts to simply 'another factor of social exclusion for the populations of foreign origin living in France' ${ }^{47}$ At best, young black French audiences identify with the heroes of American imports such as 'The Cosby Show'; at worst they find themselves alienated and marginalized by such negative stereotypes as drug dealers and pimps.

Despite much controversy and no measurable results, Beyala and the Collectif Egalité's campaign on 'les minorités visibles' were nonetheless successful in drawing the majority ethnic French audience's attention to a very real social problem at the end of the millennium. Regrettably, it seems, however, that public awareness of the issue was both small scale and short-lived. Apart from a press conference held in June 2000 and the brief summary in La Lettre, the results of the CSA report were never published. In January 2001, CSA president Hervé Bourges was replaced by former RPR-UDF Euro-MP, Dominique Baudis, a man with apparently little interest in the issue of ethnic minorities on TV. Since then, the campaign to improve the representation of ethnic minorities appears to have fallen back into obscurity in the French media.

However, if the Collectif's campaign has yet to make a visible difference in French broadcasting, it has certainly helped to focus the minds of programmers on the concept of a multicultural France. In June 2002, France 3 chose to stop screening the

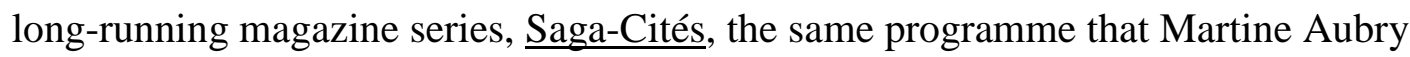
had quoted as evidence of multi-ethnic broadcasting on French TV. In response to a 
petition signed by 2900 people protesting against the decision, Bertrand Mosca, Programme Director for France 3, wrote the following:

France 3 désire refléter plus nettement la réalité pluriculturelle française tant pour le choix des acteurs que pour celui des thèmes. Par ailleurs, avec le FASILD [Fonds d'Action et de Soutien pour l'Intégration et la Lutte contre les Discriminations], France 3 met en place des liens institutionnels qui permettent de sensibiliser plus régulièrement l'ensemble de nos équipes de programmes à ces questions (séminaire annuel commun, comité éditorial, post relais). ${ }^{48}$

In place of 'Saga-Cités', France has scheduled a new monthly documentary series, 'Chez moi la France', launched in September 2003, which included a film by wellknown ‘beur' director, Yamina Benguigui entitled, 'Aïcha, Mohamed, Chaïb... engagés pour la France'. Other new France 3 programmes within the improved multicultural remit are 'SOS 18' (featuring France Zobda as a firefighter), 'Famille d'accueil' (in which Smaïl Mekki works for the DASS) and 'Fabien Cosma' (starring Louis-Karim Nebati). Nadjette Maouche has also been employed to present the France 3 morning magazine programme, 'Vivre ensemble'. ${ }^{49}$ However, as Catherine Humblot observes, 'ce n'est pas assez' since the other channels have so far failed to follow suit. ${ }^{50}$ Moreover, the new black faces are all mixed-race or 'beur'; French citizens of black African origin continue to represent the 'invisible minority' on the small screen.

Regrettably, despite France 3's efforts, the national picture remains virtually unchanged. In an open letter published in Le Monde in September 2003, Zaïr Kedadouche, attempts to draw CSA President, Baudis's attention to the continued lack of black faces on French TV. Quoting De Gaulle and reiterating his pro- 
Republican stance, Kedadouche focuses on the 'quasi-absence des Français blacks ou beurs dans la présentation des émissions de télévision' asking, 'La télévision seraitelle devenue un lieu d'exclusion des personnes uniquement parce que leur couleur de peau ou leur prénom sont différents? Pourquoi le présentateur du journal de TF1 ou de France Télévisions ne serait-il pas un journaliste black? ${ }^{51}$

Ultimately, France needs to take a long, hard look at the way its identity as a modern nation is reflected in the visual media. A huge gap certainly exists between the multi-cultural reality that is contemporary France and its homogeneously white representation on national TV. According to Malonga, this gap is symptomatic of a fundamental problem: the hypocritical notion of Republican values:

La télévision française tend à être le modèle réduit d'une société frileuse, hostile à la différence, niant un multiculturalisme pourtant évident. Le petit écran, comme la société, semble refuser l'idée d'une France multiculturelle, comme si l'égalité et la différence restaient deux notions totalement incompatibles. Notre télévision révèle donc toute la contradiction, voire l'hypocrisie, du projet égalitariste et universaliste de la République française qui, tout en se revendiquant 'une et indivisible' exclut parfois une partie de ses citoyens. $^{52}$

What the figure of Beyala as a media icon and the failure of the CSA study both confirm is the resistance of French television and, by extension, the French nation, to recognise the multiculturalism of France. It remains to be seen whether public Programme Directors such as Bertrand Mosca will actually implement change. For the moment, as Calixthe Beyala commented on French television, 'Si on vous dit que ce pays est un pays multiracial [...], vous allez en douter' ${ }^{53}$ 


\section{$\underline{\text { Notes and References }}$}

1. Calixthe Beyala quoted in MATAILLET, D., 'Qui êtes-vous .... Calixthe Beyala?', Sépia, 13 (1993), pp. 3-7 (pp. 6-7).

2. Collectif Egalité was founded in 1998. Its members include Manu Dibango, Princesse Erika, Diedonné, Luc Saint-Eloi, and le Secteur A (Passy, Doc Gynéco and Stommy Bugsy).

3. DECUGIS, J-M., and DURAND-SOUFFLAND, S., 'Positions tranchées sur les quotas', Le Figaro (1 juillet 1999).

4. FRACHON, C., and VARGAFTIG, M., (eds), European Television: Immigrants and Ethnic Minorities (John Libbey, 1995), p.149. The first British sitcom to be written for and starring black British people was The Fosters (featuring a young Lenny Henry) broadcast by LWT in 1976. I am not suggesting here that racism is not an issue on British TV; rather that the visibility of black people in the media is far greater in the UK than in France.

5. Quoted in BERTHIER, S., 'Le profil à doc', Télérama (28 November 2001). Before moving into television, Nébati spent two and a half years at the Comédie Française

6. M.N., 'La devise de Calixthe Beyala: Liberté, Egalité et Mixité', L'Evénement, 612 (mai 1999).

7. M.N., 'La devise de Calixthe Beyala'. 'Saga-Cités' was a weekly magazine programme about life in the Parisian 'banlieues' and broadcast at midday on Sundays for more than ten years. See below for further discussion of this programme.

8. La Lettre du CSA, 129 (juin 2000), p. 26.

9. The first study was carried out by the CIEMI (Centre pour l'Information et l'Etude des Migrations Internationale) and culminated in the publication of PEROTTI, A., 'Présence et représentation de l'immigration et des minorités ethniques à la télévision française', Migrations Société, 3.18 (1991), 39-55. See MCGONAGLE, J.M.'s recent article, Ethnicity and Visibility in Contemporary French Television, French Cultural

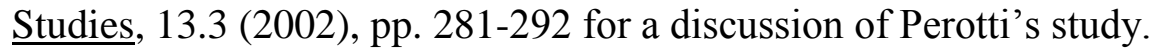

10. MALONGA, M-F., 'Ethnic Minorities: which Place and which Image on French Television?'

[www.lse.ac.uk/collections/EMTEL/Minorities/papers/franceminorepres.doc] La Cinquième was not included as its programming ends at 19.00; Arte was also excluded as its broadcasting begins at 19.00 and, as a Franco-German channel, it is not monitored by the CSA. See the summary of the unpublished report, 'Présence et représentation des minorités visibles à la télévision française: une étude du CSA', La Lettre du CSA, 129, pp. 12-14.

11. MALONGA, 'Ethnic Minorities'.

12. I am very grateful to Marie-France Malonga for providing me with further information about the CSA study.

13. MALONGA, 'Ethnic Minorities'.

14. ibid.

15. Désir quoted in DECUGIS and DURAND-SOUFFLAND, 'Positions tranchées'., KEDADOUCHE, Z., 'Rebonds', Libération (15 novembre 1999).

16. Mouvement contre le racisme et pour l'amitié entre les peuples.

17. Quoted in ZAPPI, S., 'Gouvernements et associations rejettent l'exigence des quotas', Le Monde (22 mai 2000). 
18. KEDADOUCHE, 'Rebonds'.

19. BLANCHARD, P., and BANCEL, N., De l'indigène à l'immigré (Gallimard, 1998) p. 85.

20. Radio interview on 'Le vif du sujet', France Culture, 18 juillet 2000.

21. 'La 25ème nuit des César', Canal +, 19 février 2000. The statement read by

Beyala and Saint-Eloi is reproduced in the former's published essay, Lettre d'une

Afro-française à ses compatriotes (Mango, 2000).

22. La Lettre du CSA, 129, p.13

23. Frédéric Beigbeder, 'La case de tante Beyala', Elle (14 octobre 1996).

24. There are twelve recorded appearances for this year in the copyright archives of the Institut National de l'Audiovisuel (INA) in Paris.

25. 'J'y crois j'y crois pas', TF1, 2 mai 1996.

26. 'Le vrai journal', Canal +, 29 septembre1996.

27. 'A tout savoir', La Cinquième, 11 octobre 1996.

28. 'Journal de 20 heures', TF1, 30 octobre 1996.

29. See, for example, Thierry Beccaro in 'Matin Bonheur', Antenne 2, 8 décembre 1987. Much of Beccaro's interview with Beyala consists of whole-screen close-up shots of her face. See also Serge Moati in 'Ripostes', La Cinquième, 28 mai 2000. 30. 'A la Folie', TF1, 25 octobre 1987.

31. See, 'Matin Bonheur', Antenne 2, 8 décembre 1987.

32. 'Matin Bonheur', Antenne 2, 20 septembre 1988.

33. 'Durand la Nuit', TF1, 29 juin 1993.

34. PONTIE, E., 'Belleville à l'honneur', Afrique Magazine (mai 1999).

35. BEYALA, C., Lettre d'une Africaine à ses soeurs occidentales (Spengler, 1995)

During the programme, Beyala misquotes the title of her book as Lettre ouverte aux femmes occidentales.

36. 'Tout le monde en parle', Antenne 2, 23 octobre 1999.

37. 'On a tout essayé!', France 2, 3 octobre 2000.

38. BHABHA, H.K., 'The other question: the stereotype and colonial discourse', Screen, 24.4 (1983), p.18.

39. See BLANCHARD and BANCEL, De l'indigène à l'immigré for a visual history of these images.

40. ROSS, K., Black and White Media: Black Images in Popular Film and Television (Polity, 1996), p.xxii.

41. CHALAYE, S., 'Autour du “Collectif Egalité": Entretien avec Jacques Martial', Africultures, 27 (2000), pp. 43-48 (p. 45). Marital plays Bain-Marie in the longrunning series, 'Navarro'.

42. ROSS, p. 170.

43. ALLISON, M. 'Women and the Media', in GREGORY, A. \& U. TIDD(eds), Women in Contemporary France (Berg, 2000), pp.65-87 (p.68)

44. THOMAS, D., 'Francophone Studies in Global Contexts', FrancophonePostcolonial Studies, 1.1 (2003), pp. 92-99 (p. 96).

45. 'Bouvard des succès', France 2, 26 août 2000.

46. BLANCHARD and BANCEL, De l'indigène à l'immigré, p. 83.

47. MALGONA, 'Ethnic Minorities'.

48. Letter reproduced on the website of Acrimed (Action Critique Médias)

[http://acrimed.samizdat.net/imprimer.php3?id_article=249]

49, HUMBLOT, C., 'La télé n'est toujours pas multicolore', Le Monde (27

septembre 2003).

50. ibid. 
51. KEDADOUCHE, Z., 'Ecrans pâles', Le Monde, 4 septembre 2003.

52. MALONGA, M-F., 'Fictions TV: des Noirs dans l'ombre', Africultures, 27 (2000), pp. 34-7 (pp. 36-7). Malonga's emphasis.

53. 'Rince ta baignoire', Antenne 2, 22 septembre 1999. 